\title{
TINJAUAN HUKUM ISLAM TERHADAP PRAKTIK TABUNGAN PEMBERDAYAAN KESEJAHTERAAN KELUARGA (PKK) DI KAMPUNG WIANTRE DISTRIK SKANTO KABUPATEN KEEROM
}

\author{
Andri Setiawan \\ IAIN Fattahul Muluk Papua \\ foursixczmezter@gmail.com \\ Moh. Wahib \\ IAIN Fattahul Muluk Papua \\ Ira Eka Pratiwi \\ IAIN Fattahul Muluk Papua \\ irax23@gmail.com
}

\begin{abstract}
ABSTACT
This study aims to discuss the practice of (Pemberdayaan Kesejahteraan Keluarga) PKK saving in Wiantre Village, Skanto District, Keerom Regency in the perspective of Islamic Law . PKK savings are savings that cannot be taken at any time. The object of this study is the application of Qardh agreement. Which in this practice of PKK Savings, there is interest has been determined at the beginning based on a percentage equivalent to 2.5 percent of the last balance.

It is field research using a qualitative method. The primary data in this study was the result of the interview with the managers of PKK Savings in Kampung Wiantre, Skanto District, Keerom Regency, the members, and the chief of Indonesia Ulema Council of the Keerom Regency.

The result of this study shows that based on Islamic Law perspective, the PKK Savings practices in Wiantre Village, Skanto District, Keerom District, used Qardh contracts as the agreement between the savers and managers. However, even though there is interest system in this practice, but it is halal since the funds that come to the managers are used for the social benefit.
\end{abstract}

Keywords : Qardh, Interest, PKK Savings, Keerom Regency, Islamic Law 


\begin{abstract}
ABSTRAK
Artikel ini membahas tentang Tinjauan Hukum Islam Terhadap Praktik Tabungan Di Kampung Wiantre Distrik Skanto Kabupaten Keerom. Tabungan PKK merupakan tabungan yang tidak dapat di ambil sewaktu-waktu. Objek yang penuis ambil untuk penelitian tabungan yang pengaplikasiannya menggunakan akad Qardh. Yang dalam praktiknya terdapat bunga sudah ditentukan di awal berdasarkan presentase yang setara dengan 2,5 persen dari jumlah saldo terakhir. Praktek tersebut membuat penulis tertarik untuk mengkaji lebih dalam.

Metode penelitian ini adalah metode kualitatif dengan jenis penelitian adalah penelitian lapangan. Sumber data primer dalam penelitian ini Merupakan hasil wawancara dengan pihak pengelola, anggota dan ketua MUI Keerom di Tabungan Pemberdayaan Kesejahteraan Keluarga (PKK) Kampung Wiantre Distrik Skanto Kabupaten Keerom.

Dari hasil penelitian Tinjauan Hukum Islam Terhadap Praktik Tabungan PKK Di Kampung Wiantre Distrik Skanto Kabupaten Keerom dapat diketahui bahwa tabungan pada akad Qardh yang di praktikkan oleh tabungan PKK terdapat bunga yang di bagi dua untuk penabung dan pengelola. Namun karena bunga dana yang masuk ke pengelola untuk kemaslahatan praktik tersebut diperbolehkan.
\end{abstract}

Kata Kunci : Qardh, Bunga, Tabungan PKK, Kabupaten Keerom, Hukum Islam.

\title{
PENDAHULUAN
}

Lembaga keuangan dan pasar keuangan mempunyai posisi kunci dalam perekonomian sebagai prantara dalam menyalurkan tabungan dan dana-dana lainnya kepada pengguna dana. Salah satu tugas utamanya adalah rekonsiliasi dan perbedaan persyaratan penabung dan pengguna dana yang memungkinkan satu tingkat tabungan dan investasi. Majunya perkembangan ekonomi industri jasa yang sangat pesat dapat dilihat dengan berkembangan lembaga-lembaga keuangan yang bermunculan di indonesia yaitu lembaga keuangan bank dan lembaga keuangan non bank.(Andri Soemitra,2009)

Lembaga keuangan bank merupakan lembaga yang memberikan jasa keuangan yang paling lengkap. Usaha keuangan yang dilakukan adalah menyalurkan dan memberikan kredit serta menghimpun dana masyarakat dalam bentuk simpanan. Serta memberikan jasa-jasa keuangan yang meng mendukung dan melancarkan kegiatan memberikan pinjaman dengan kegiatan menghimpun dana. Yang dibina dan diawasi oleh OJK. Sedang lembaga keuangan non bank merupakan lembaga keuangan yang lebih banyak jenisnya dari lembaga keuangan bank. Masing-masing lembaga non bank mempunyai ciri-ciri operasionalnya sendiri. 
Hukum Islam dalam sistem ekonomi merupakan sebuah sistem yang telah terbukti dapat mengantarkan umat manusia kepada real welfare (falah), kesejahteraan yang sebenarnya. Dalam konsep ekonomi Islam ada semenjak kehadiran agama Islam di atas bumi ini. Al-Qur'an dan hadits kaya akan hukum-hukum dan pengarahan kebijakan ekonomi yang harus diambil dan disesuaikan dengan perubahan zaman. Dalam hukum islam, harus dibedakan antara konsep dasar dengan hukum-hukum terperinci dan proses aplikasi hukum dalam konteks kehidupan ekonomi masyarkat. Konsep dasar yang di tawarkan Al-Qur'an dan hadits merupakan wacana global tentang kehidupan ekonmi yang berfungsi sebagai kerangka atas kebijakan dan langkah yang ingin direalisasikan. Sebuah konsep yang mengatur gerak langkah pelaku ekonomi dalam menjalankan kegiatan ekonomi.( DR. Said Sa'ad Marthon)

Konsep ekonomi konvensional tentang welfare yang begitu sempit dan gersang menyebabkan diabaikannya aspek ruhani umat manusia sebagaimana diarhkan semata-mata untuk meningkatkan pendapatan perkapita yang syarat aroma hedonisme dan memaksakan produk-produk ke pasaran tanpa mempertimbangkan dampak negatif bagi aspek kehidupan lain. Oleh karena itu diperlukan sistem keuangan yang baik dalam suatu negara.

Sistem keuangan merupakan tatanan perekonomian dalam suatu negara yang berperan melakukan aktivitas dalam berbagai jasa keuangan yang diselenggarakan lembaga keuangan. Tugas utama sistem keuangan adalah mengalihkan dana yang tersedia (leonable funds) dari para penabung kepada pengguna dana untuk kemudian digunakan membeli barang dan jasa-jasa di samping untuk investasi sehingga ekonomi dapat tumbuh dan meningkatkan standar kehidupan.(Andri Soemitra,2009)

Sistem keuangan memiliki fungsi yang sangat vital dalam perekonomian modern. Sistem keuangan berfungsi menyediakan mekanisme pembayaran, menyediakan dana untuk pembiayaan atau kredit, penciptaan alat pengukuran uang, dan sarana mobilasi tabungan.Sasaran fungsi sistem keuangan syariah dan konvensonal pada prinsipnya sama, yang membedakan adalah sasaran. Sasaran sistem keuangan syariah tidak terpisahkan dari ideologi keislaman yang di dasarkan pada ajaran islam (Al-Qur'an dan Sunnah), Sedangkan sasaran sistem konvensional, fungsi sistem keuangan di dasarkan pada tingkat suku bunga (interest rate).(Andri Soemitra,2009)

Pertumbuhan ekonomi di Papua, Kantor Perwakilan Bank Indonesia Papua dan Otoritas Jasa Keuangan (OJK) Papua mendorong pihak perbankan menciptakan peluang-peluang pada sektor ekonomi baru di kabupaten/kota di Papua. Sehingga sektor ekonomi di Papua tidak terbelakang, dan meningkat dari provinsi lain di Indonesia. 
Pentingnya menabung untuk investasi jangka panjang sangat perlu bagi ibu-ibu masyarakat kampung Wiantre. Tabungan PKK merupakan perpaduan tabungan dan arisan dimana nama yang sudah keluar tetap harus membayar hingga selesai. (Yushinta Mutiaraningtyas, 2004)

Keberadaan tabungan Pemberdayaan Kesejahteraan Keluarga (PKK) di kampung Wiantre diharapkan dapat memberikan kemaslahatan terbesar bagi masyarakat yang menjadi anggota Pemberdayaan Kesejahteraan Keluarga (PKK). sistem tabungan Pemberdayaan Kesejahteraan Keluarga (PKK) dalam kegiatannya menabung dan juga dipinjamkan bagi anggotanya dengan syarat dikenakan bunga yang telah ditentukan dan yang meminjam membayar bunga dan yang menabung akan mendapatkan bunga, kegiatan ini di adakan setiap tanggal 10 dan 25 Tabungan Pemberdayaam Kesejahteraan Keluarga (PKK) yang dalam pelaksanaanya terdapat kegiatan menabung dan dipinjamkan dengan ketentuan adanya bunga.

Penelitian ini berkontribusi memberikan informasi kepada masyarakat bagaimana Tinjauan Hukum Islam tentang praktik yang terjadi di tabungan Pemberdayaan Kesejahteraan Keluarga (PKK) Kampung Wiantre Distrik Sknto Kabupaten Keerom .

\section{KAJIAN LITERATUR \\ Pengertian Tabungan}

Tabungan adalah Simpanan Uang Di Bank Yang Penarikannya Hanya Dapat Dilakukan Menurut Syarat Tertentu. Umumnya bank akan memberikan buku tabungan yang berisi informasi seluruh transaksi yang anda lakukan dan kartu atm lengkap dengan nomor pribadi (PIN). Dalam perkembangannya saat ini, terdapat beberapa jenis tabungan yang tidak lagi menggunakan buku tabungan.( OJK,2020) Jadi dapat disimpulkan bahwa tabungan adalah simpanan yang penarikannya hanya dapat dilakukan menurut syarat tertentu. Tetapi tidak dapat ditarik dengan cek, bilyet, giro dan lainnya. Jika hendak mengambil simpanan harus datang ke bank dengan membawa biku tabungan, slip penarikan, atau melalui fasilitas ATM.

\section{Jenis-jenis Tabungan}

a. Tabungan Konvensional

Tabungan konvensional merupakan jenis tabungan yang banyak di pakari oleh masyarakat indonesia.tabungan ini populer karna pengajuannnya cepat dan mudah.

b. Tabungan berjangkaTabungan berjangka disediakan tabungan tertentu yang dalam pengambilannya sesuai waktu yang di tentukan.

c. Tabungan Haji 
Tabungan haji adalah jenis tabungan yang diberikan yang diberikan oleh tabungan bank untuk memudahkan nasabahnya melaksanakan ibadah haji.

d. Tabungan investasi

Tabungan ini diperuntukkan untuk para broker yang membeli saham dan menyimpan laba dalam transaksi.

e. Tabungan anak

Tabungan anak merupakan tabungan yang diperuntukkan untuk anak agar belajar berhemat.

f. Tabungan giro adalah tabungan khusus untuk transaksi bisnis dan diperuntukkan bagi perusahaan.

g. Tabungan mata uang asing

Tabungan ini dapat disebut juga dengan investasi karna saat terjadi kenaikan nilai mata uang kita akan mendapat dari investasi ini.(Kompas, 2020)

\section{Pengertian Qardh}

Kata qardh berasal dari bahasa Arab qirad yang memiliki arti 'memotong'. qardh merupakan pemotongan sebagian kekayaan peminjam (lender) dengan memberikan pinjaman (loan) kepada penerima pinjaman (borrower).( Sutan Remy Sjahdeini,2014)

pinjaman qardh biasanya adalah uang atau alat tukar lainnya, yang digunakan untuk transaksi pinjaman tanpa bunga ketika peminjam mendapatkan uang tunai dari pemilik dana (dalam hal ini bank) dan hanya wajib mengembalikan pokok utang pada waktu yang telah di tentukan. (Ascarya, 2012)

Para Golongan Hanafiyah memiliki pendapat bahwa qardh adalah akad tertentu atas penyerahan harta kepada orang lain agar orang tersebut mengembalikan dengan nilai yang sama. Para Golongan Syafi'iyah menyatakan bahwa qardh adalah kepemilikan sesuatu benda atas dasar dikembalikan dalam nilai yang sama. Hanabilah menyatakan bahwa qardh adalah menyerahkan harta kepada orang yang memanfaatkan dengan ketentuan mengembalikan gantinya. Sayyid Sabiq menjelaskan qardh adalah harta yang diberikan kepada yang berutang agar dikembalikan dengan nilai yang sama kepada pemiliknya ketika orang yang berhutang mampu membayar. Jelasnya, qardh atau utang piutang adalah akad antara dua pihak, satu pihak menyerahkan hartanya kepada pihak yang lain dengan ketentuan pihak yang 
menerima harta mengembalikan kepada pemiliknya dengan nilai yang sama.

\section{Dasar Hukum Qardh}

Utang-piutag dalam islam di perbolehkan berdasarkan al-Quran, al-hadits maupun ijma ${ }^{\text {ee }}$ sebagai berikut:

1) Landasan al-Quran

QS. al-Baqarah [2] ayat 245:

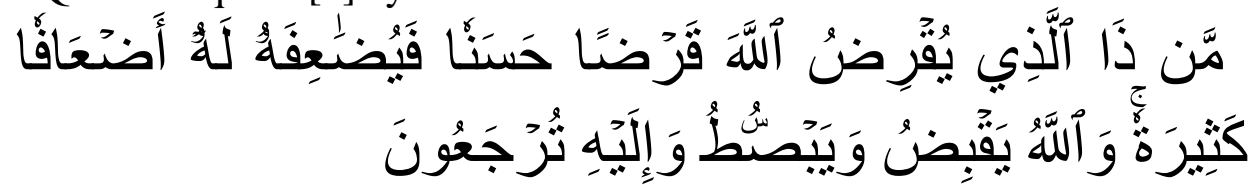

"Barang siapa meminjami Allah dengan pinjaman yang baik maka Allah melipatgandakan ganti kepadanya dengan banyak. Allah menahan dan melapangkan (rezeki) dan kepada-Nyalah kamu dikembalikan".

QS. al-Maidah [5] ayat 2:

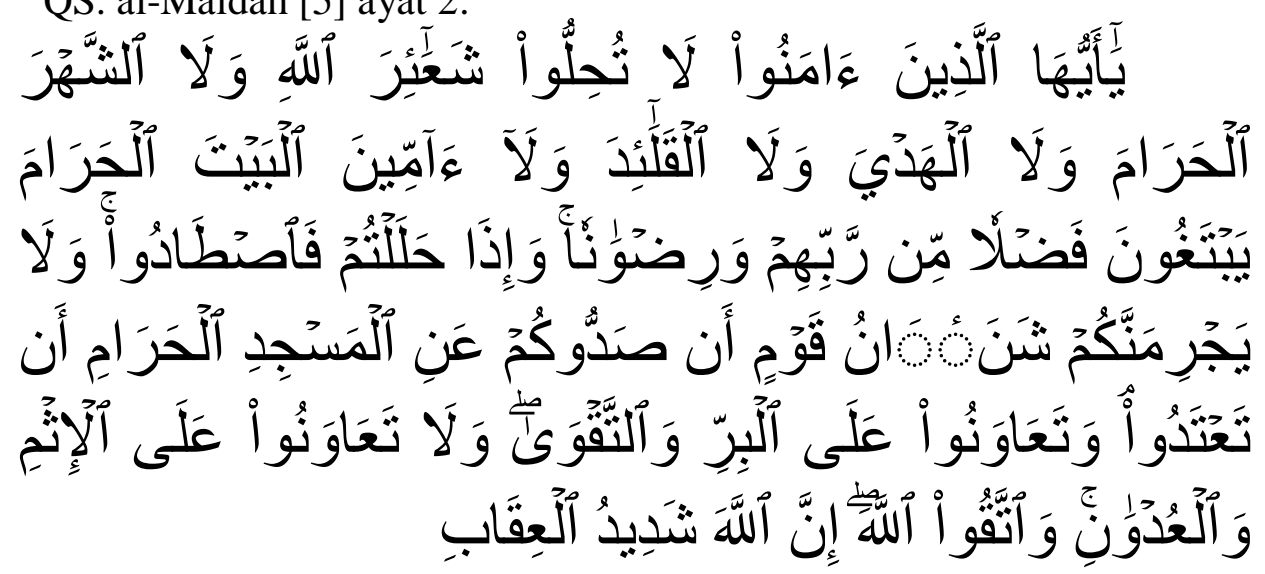

“ Hai orang-orang yang beriman, janganlah kamu melanggar syi'ar-syi'ar Allah, dan jangan melanggar kehormatan bulan-bulan haram, jangan (mengganggu) binatang-binatang had-ya, dan binatangbinatang qalaa-id, dan jangan (pula) mengganggu orang-orang yang mengunjungi Baitullah sedang mereka mencari kurnia dan keridhaan dari Tuhannya dan apabila kamu telah menyelesaikan ibadah haji, maka bolehlah berburu. Dan janganlah sekali-kali kebencian(mu) kepada sesuatu kaum karena mereka menghalang-halangi kamu dari Masjidilharam, mendorongmu berbuat aniaya (kepada mereka). Dan tolong-menolonglah kamu dalam (mengerjakan) kebajikan dan takwa, dan jangan tolong-menolong dalam berbuat dosa dan pelanggaran. Dan bertakwalah kamu kepada Allah, sesungguhnya Allah amat berat siksa-Nya." 
Ayat-ayat diatas berisi tentang anjuran untuk memberikan pinjaman atau Qardh kepada orang yang membutuhkan, sebagaimana imbalannya dilipatgandakan oleh Āllah SWT.

Dari orang yang memberikan hutang atau muqridh. Didalam Islam menganjurkan umatnya untuk membantu kepada sesama yang membutuhkan dengan cara memberi pinjaman atau utang. Dari pandangan muqtaridh, utang merupakan sesuatu perbuatan yang dilarang, tetapi diperbolehkan dikarenakan orang yang berutang dengan tujuan untuk memanfaatkan barang atau uang yang diutangnya untuk membantu memenuhi kebutuhan hidupnya, dan ia akan mengembalikannya sama dengan jumlah seperti yang diterimanya

Landasan Hadis Ibnu Mas ${ }^{e e} u d:$

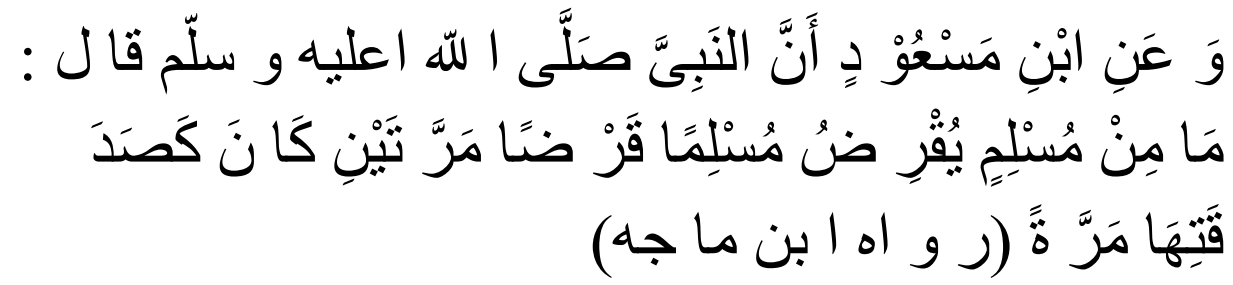

“ Diriwayatkan dari ibnu mas'ud sesungguhnya Nabi Saw, berkata: Tidaklah seorang Muslim menghutangkan hartanya kepada Muslim lain sebanyak dua kali kecuali perbuatannya sama dengan sedekah.(HR. Ibnu Majah)

Dari hadits tersebut dapat di simpulkan bahwa qardh atau pinjaman adalah sesuatu perbuatan yang direkomendasikan, yang dijamin Allah diberi imbalan. Dalam hadits menjelaskan bahwasannya memberikan utang atau pinjaman dua kali nilainya sama dengan sekali memberi sedekah. hal dapat diartikan bahwa qardh merupakan perbuatan yang yang baik karna membantu antara orang yang kelebihan dana dan orang yang orang yang membutuhkan dana untuk memenuhi kehidupannya .

3) Ijma' para Ulama

Para Ulama telah Ijma' tentang kebolehan utang piutang. bagi orang yang memberikan utang adalah sunnah sedangkan hukum qardh bagi yang berhutang bersifat mubah. (Rozalinda, 2016)

\section{Rukun Qardh}

a. Dua orang atau pihak sebagai muqrud atau orang yang hendak memberikan hutang dan muqtarid atau pihak yang akan berhutang. 
b. Barang yang akan dipinjamkan.

c. Ijab dan kabul.

\section{Syarat Qardh}

a. Kerelaan antara kedua belah pihak.

b. Dana berasal dari harta yang halal.

c. Syarat dihitung (addiyat).( Sutan Remy Sjahdeini,2014)

\section{Ketentuan Hukum dalam Akad Qardh}

Beberapa ketentuan hukum dalam akad qardh adalah sebagai berikut:

1. Tidak boleh ada tambahan

Larangan adanya tambahan dapat dipahami pada diktum pertama point 2 Fatwa DSN MUI No. 19 Tahun 2001 tentang al-qardh, dinyatakan bahwasannya "Nasabah al-qardh wajib mengembalikan jumlah pokok yang diterima pada waktu yang tealah disepakati bersama".37 Nasabah alqardh dapat memberikan tambahan (sumbangan) dengan sukarela kepada bank selama mengenai hal itu tidak diperjanjikan dalam akad.( Sutan Remy Sjahdeini,2014)

2. Tidak boleh ada denda keterlambatan pelunasan.

Atas keterlambatan yang benar-benar disebabkan ketidak mampuan nasabah, ada dua sikap yang harus diputuskan oleh pihak kreditur:

a) Memperpanjang jangka waktu pengenbalian, atau

b) Menghapuskan sebagian atau seluruh kewajibannya.

Keputusan pemberian sanksi keterlambatan pelunasan hanya diberlakukan terhadap nasabah mampu dan sengaja bersikap tidak amanah. Sanksi tersebut bisa berupa penjualan barang jaminan dan bisa juga berupa denda. (Ghufron Ajib,2016)

3. Jaminan

Menurut prinsip syariah tidak dilarang bagi kreditur untuk meminta jaminan dari debitur, yaitu jaminan atas pengembalian atau pelunasan pinjaman kreditur kepada debitur. Sesuai prinsip syariah, jaminan tersebut dapat berupa barang (agunan) marhun, baik milik debitur sendiri maupun pihak ketiga. Dapat pula jaminan tersebut merupakan penjaminan/penanggungan (quarantee) yang diberikan oleh seorang penjamin/ penanggung (guarantor) baik penjamin orang perseorangan/ individu maupun penjamin korporasi. 


\section{Pendapat Para Ulama Tentang Bunga}

Para ulama kontemporer berbeda pendapat tentang hukum bunga bank. Pertama, ulama yang terdiri dari Yusuf Qaradhawi, Mutawalli Sya'rawi, Abu Zahrah, dan Muhammad al-Ghazali, menyatakan bahwa bunga bank hukumnya haram, karena termasuk riba. Pendapat ini berasal dari forum ulama Islam, meliputi: Majma' al-Fiqh al-Islamy, Majma' Fiqh Rabithah al-'Alam al-Islamy, dan Majelis Ulama Indonesia (MUI). Dengan pedoman dalil diharamkannya riba adalah dalam Al-Qur'an Surat alBaqarah ayat 275:

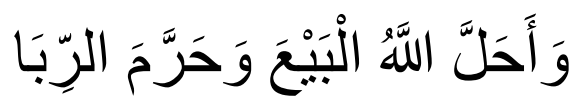

"Padahal Allah telah menghalalkan jual beli dan mengharamkan riba."

Kedua, Ulama kontemporer yanf terdiri dari, Syekh Ali Jum'ah, Muhammad Abduh, Abdul Wahab Khalaf, Muhammad Sayyid Thanthawi, dan Mahmud Syaltut, menegaskan bahwa bunga bank hukumnya boleh dan tidak termasuk riba. Pendapat ini sejalan dengan fatwa Majma' al-Buhus alIslamiyyah yang ditetapkan tanggal 23 Ramadhan $1423 \mathrm{H}$, atau dalam masehi tanggal 28 November 2002 .Mereka berpedoman pada firman Allah pada Surat an-Nisa' ayat :

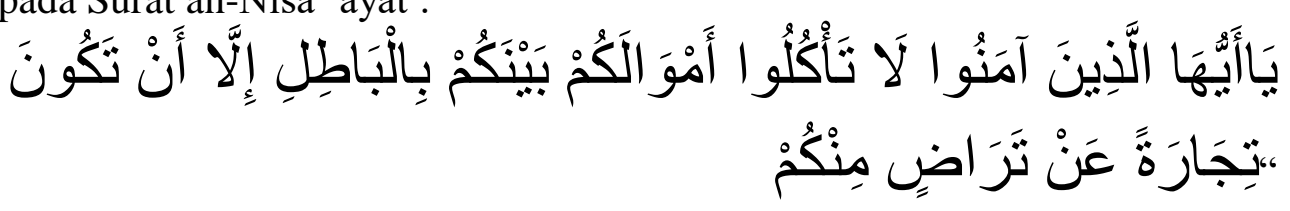

"Hai orang-orang yang beriman, janganlah kamu saling memakan harta sesamamu dengan jalan yang batil, kecuali dengan jalan perniagaan yang berlaku dengan suka sama suka di antara kamu."

Pada ayat di atas, Allah melarang memakan harta orang lain dengan cara yang batil, dengan cara riba. Akan tetapi, Allah menghalalkan hal itu jika dilakukan dengan perniagaan yang berjalan dengan saling ridho. Karenanya, keridhaan kedua belah pihak yang bertransaksi untuk menentukan besaran keuntungan di awal, sebagaimana yang terjadi di bank, dibenarkan dalam Islam.Di samping itu, mereka juga beralasan bahwa jika bunga bank itu haram maka tambahan atas pokok pinjaman itu juga haram, sekalipun tambahan itu tidak disyaratkan ketika akad. Akan tetapi, tambahan dimaksud hukumnya boleh, maka bunga bank juga boleh, karena tidak ada beda antara bunga bank dan tambahan atas pokok pinjaman tersebut. 


\section{Jenis Penelitian}

Metode Penelitian ini merupakan jenis penelitian lapangan menggunakan metode kualitatatif. metode kualitatif berasal dari para ilmuan Antropologi dan Sosiologi. Metode kualitatif, dipengaruhi oleh teori kritis, tertatik untuk mengetahui bagaimana orang membuat pilihan dan bertindak dalam masyarakat.( J.R Raco, 2010) sehingga dalam mengumpulkan informasi dapat menemukan jawaban atas permasalahannya.

Metode penulisan kualitatif ini dapat menjelaskan permasalahan atau feomena yang terjadi menurut persepsi dari seseorang ataupun kelompok dengan mendeskripsikan kejadian dengan ketentuan dan yang dapat di tarik benang merahnya melalui wawancara di sertai hasil analisis, dokumen, dan catatan-catatan yang dapat di simpulkan. (Asep, 2012) Yang nantinya akan penulis lakukan penelitian pada Tinjauan Hukum Islam Terhadap Praktik Tabungan Pemberdayaan Kesejahteraan Keluarga (PKK) Di Kampung Wiantre Distrik Skanto Kabupaten Keerom.

\section{Lokasi dan Waktu Penelitian}

Dalam observasi ini, penulis mengambil lokasi di Kampung Wiantre Distrik Skanto Kabupaten Keerom dengan target anggota Pemberdayaan Kesejahteraan Keluarga (PKK) . Waktu penelitian tanggal 1 Februari hingga Akhir Maret tahun 2020.

\section{Subjek dan Objek Penelitian}

Subjek penelitian adalah merujuk pada responden, informan yang akan di gali datanya. Maka subyek penelitian ini adalah anggota Pemberdayaan Kesejahteraan Keluarga (PKK). (Sugiono, 2013)

Objek penelitian merupakan sesuatu yang berkaitan dengan tema yang di teliti. Maka obyek yang diteliti tinjauan hukum islam terhadap praktik tabungan Pemberdayaan Kesejahteraan Keluarga (PKK).( Muh. Fitrah, 2017)

\section{Sumber Data}

Data Primer adalah data yang diperoleh atau dikumpulkan langsung dilapangan oleh orang yang melakukan penelitian melalui wawancara dan observasi.

Data Sekunder adalah data yang diperoleh atau dikumpulkan oeleh orang yang melakukan penelitian dari sumber-sumber yang telah ada. 


\section{Metode Pengumpulan Data}

Wawancara adalah mengumpulkan informasi dengan mengajukan pertanyaan dengan sistem tanya jawab. Metode ini dilakukan dengan tatap muka antara pencari informasi dengan sumber informasi. pertanyaan harus menggunakan bahasa yang baik dan tidak menyinggung. (DR.J.R. Raco ,2010) pertanyaan yang diajukan harus menekankan kepada arti agar penulis tidak bingung menghadapi kosa kata yang tidak baku yang diucapkan oleh narasumber. Peneliti mengambil sampel sebanyak 15 informan dari anggota Pemberdayaan Kesejahteraan Keluarga (PKK) untuk diteliti. Dengan 1 pakar hukum Islam baik dari pemuka agama ataupun dari Majelis Ulama Indonesia (MUI) Provinsi Papua.

a. Observasi

Observasi adalah bagian dari pengumpulan data, observasi berarti mengumpulkan data langsung dari lapangan. data yang di observasi berupa gambaran tentang sikap, kelakuan, prilaku, dan tindakan keseluruhan interaksi antar manusia. (Muru Yusuf 2014)

b. Dokumentasi

Dokumentasi merupakan data dalam bentuk foto, video, catatan, surat berupa pernyataan yang bisa di gunakan sebagai informasi tambahan.

c. Trianggulasi

Teknik trianggulasi merupakan cara untuk mendapatkan akurasi data dan informasi dengan membandingkan antara hasil wawancara dengan observasi, membandingkan hasil wawancara dengan dokumen yang ada.Trianggulasi merupakan pendekatan multimetode, dilakukan peneliti ketika mengumpulkan dan menganalisis data. Pemikiran dasarnya bahwa fenomena penelitian dapat dipahami dengan baik dan diperoleh tingkat validitas tinggi jika didekati dari berbagai dimensi. (Firdaus dan Fakhry Zamzam, 2016)

\section{Analisis Data}

Tehnik analisisi data menggunakan tehnik dari Miles dan Huberman yang membagi kegiatan menjadi beberapa bagian yaitu penguumpulan data, reduksi, penyajian data, dan penarikan kesimpulan. Tehnik ini juga menggunakan model "Analysis Interactive". 
Gambar 3. 1 Analisis Interaktif Model dari Miles dan Huberman

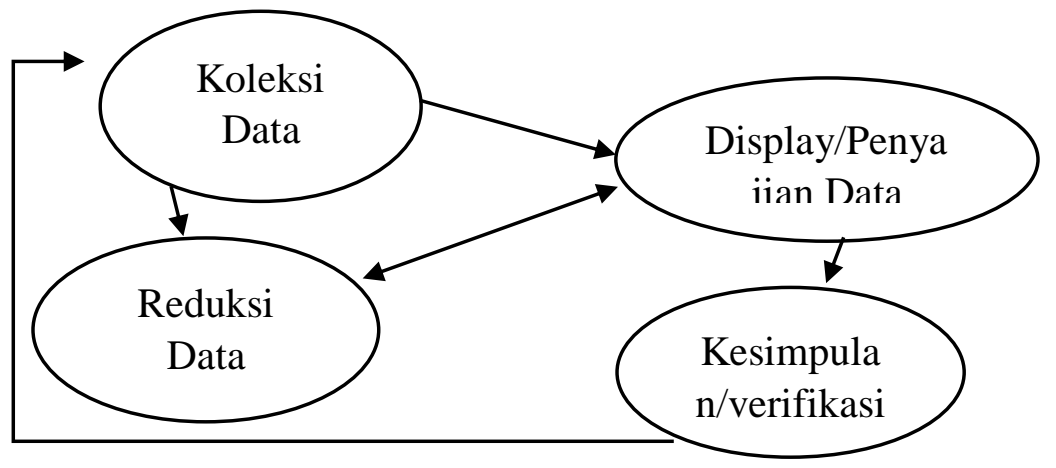

1. Proses reduksi data diartikan sebagai proses pemilihan, pemusatan perhatian pada penyederhanaan, pengabstrakan, transformasi data yang tertulis di lapangan.

2. Penyajian data menurut Miles dan Hubberman membatasi suatu penyajian sebagai sekumpulan informasi tersusun yang memberi kemungkinanadanya penarikan kesimpulan dan pengambilan tindakan.

3. Kagiatan menarik kesimpulan sebagai suatu konfigurasi yang utuh dengan meninjau catatan-catatan di lapangan.

Berdasarkan gambar diatas, secara umum analisa data dalam penelian ini dilakukan melalui tahapan-tahapan sebagai berikut:

a) Mencatat semua temuan fenomena di lapangan baik melalui pengamatan, wawancara, dan dokumentasi.

b) Menelaah kembali catatan hasil pengamatan, wawancara dan studi dokumentasi, serta memisahkan data yang dianggap penting dan tidak penting.

c) Mendeskripsikan data yang telah diklarifikasikan dengan memperhatikan fokus dan tujuan penelitian.

d) Membuat analisis akhir dalam bentuk laporan hasil penelitian. ( Ilyas, 2018)

Penelitian ini menggunakan pengamatan dengan strategi pengamatan Deskriptif dengan menafsirkan, memaparkan dan menganalisa data yang ada. (Hadari Nawawi, 1991) Pendekatan penelitian ini menggunakan pendekatan kualitatif yaitu mengambil data dari kata-kata atau lisan dari informan sebagai sumber informasi untuk memecahkan masalah peneliti.

\section{HASIL DAN PEMBAHASAN}

\section{Hasil}

Untuk bunga yang menyimpan uang ditetapkan sebesar 2,5 persen dengan pembagian penyimpan dana mendapatkan 1,25 persen dan masuk ke kas PKK sebesar 1,25 persen dimana dana dari bunga tersebut digunakan untuk kegiatan- 


\section{El Mudhorib: Jurnal Kajian Ekonomi dan Perbankan Syariah \\ Vol. 2 No. 1 Desember 2020 \\ E-ISSN: 2722-5615}

kegiatan PKK seperti kegiatan kesehatan seperti sosialisasi kesehatan dan lomba senam, kegiatan pendidikan membantu sekolah untuk mengadakan kegiatan lomba atau kegiatan kerajinan untuk menambah wawasan anak-anak sekolah khususnya di Sekolah Dasar yang ada di Kampung Wiantre ini, serta kegiatan sosial untuk digunakan kegiatan dikampung seperti lomba tumpeng, serta untuk kegiatan keagamaan seperti membantu membeli Iqra dan sebaginya.

\section{Pembahasan}

Dalam praktik tabungan PKK yang terdapat di Kampung Wiantre Distrik Skanto Kabupaten Keerom terdapat prktikdengan ketentuan praktik yang dijalankan setiap nasabah tidak bisa di ambil sewaktu-waktu dan peminjam akan dikenakan bunga sebesar 2,5 persen. Dimana bunga 2,5 persen tersebut di bagi dua untuk nasabah dan organisasi kemasyarakatan yaitu PKK di Kampung Wiantre Distrik Skanto Kabupaten Keerom untuk dana sosial. Dengan ketentuan tersebut maka praktik tersebut tidak masalah di pergunakan karena untuk kemaslahatan.

\section{Gambar 4.2.1 Skema Tabungan}

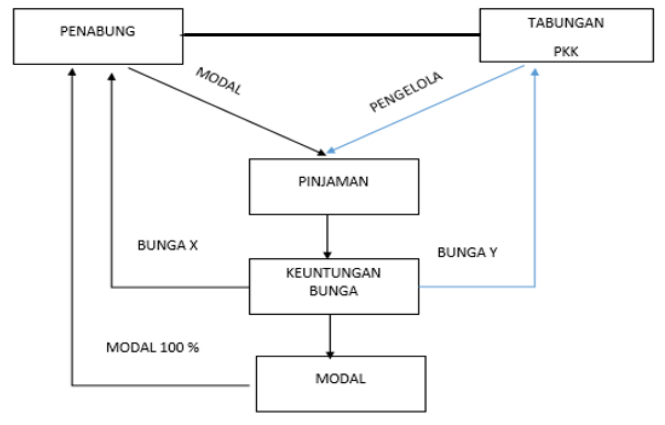

Keterangan:

1. Penabung mendatangi pengelola tabungan PKK.

2. Pengelola memberitahu tentang prosedur tabungan.

3. Dana dari nasabah di pinjamkan dengan bunga 2,5 persen.

4. Dari keuntungan bunga 2,5 persen dari jumlah tabungan tiap nasabah dibagi dua antara penabung dan pengelola dana masing-masing mendapatkan bunga 1,25 persen. Dana yang masuk Pemberdayaan Kesejahteraan Keluarga (PKK) tidak untuk pengelola melainkan masuk ke kas.

5. Dana penabung diambil kembali saat akhir tahun.

Menurut penelitian terdahulu yang berjudul tinjauan hukum Islam terhadap pelaksanaan akad mudharabah pada simpanan berkah discounted' yang menyatakan bahwa dari tinjauan hukum Islam, maka pelasanaan mudharabah 


\section{El Mudhorib: Jurnal Kajian Ekonomi dan Perbankan Syariah \\ Vol. 2 No. 1 Desember 2020 \\ E-ISSN: 2722-5615}

pada simpanan berkah discounted di BMT tidak sesuai. Ketidaksesuaiannya terletak pada presentase pada jumlah modal yang diberikan oleh anggota penabung, proporsi bagi hasil dihitung hanya dari keuntungan, tidak termasuk modal. Namun jika dana tersebut untuk dana sosial maka tidak hara

Dalam Al-Qur'an telah dijelaskan bahwa sesama manusia harus saling tolong menolong hal ini sejalan dengan firman Allah yang terdapat pada AlQuran surat Al- Maidah : 2

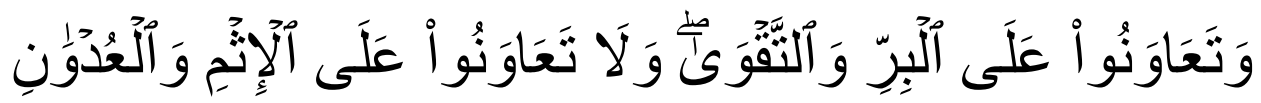

"Dan tolong-menolonglah kamu dalam (mengerjakan) kebajikan dan takwa, dan jangan tolong-menolong dalam berbuat dosa dan pelanggaran. Dan bertakwalah kamu kepada Allah, sesungguhnya Allah amat berat siksa-Nya”.

Dalam ayat tersebut menjelaskan bahwa dianjurkan untuk saling tolong menolong dalam hal kebaikan, khususnya tolong menolong dalam bermuamalah papda praktik simpan pinjam di dalam islam.

Menurut ulama kontemporer terdapat dua pendapat tentang hukum bunga. Dari kalangan ulama pertama yang terdiri dari Yusuf Qharfdawi, Mutawalli Sya'rawi, Abu Zahrah dan Muhammad Al-Ghazali menyatakan bahwa riba. Sedangkan menurut ulama kontemporer yang kadua yang terdiri dari Syekh Ali Jum'ah, Muhammad Abduh, Abdul Wahab Khalaf, Muhammad Sayyid Yhanthawi dan Mahmud Syaltut menyatakan bunga boleh dan bukan Riba.

Pada Munas 'Alim Ulama NU yang dilakukan di lampung tahun 1992 terdapat tiga pendapat yang pertama menyatakan bunga sama dengan riba jadi hukumnya haram, pendapat kedua mengatakan bahwa bung tidak sama dengan riba jadi hukumnya adalah boleh, pendapat ketiga menyatakan bahwa bunga bank syubhat. Namun pada pertemuan tersebut masih diperlukan solusi yang sesuai dengan hukum Islam.

Dari beberapa penjelasan diatas dapat disimpulkan bahwa dalam menentukan bunga merupakan masalah keyakinan. Ada sebagian ulama yang mengatakan riba dan ada yang membolehkannya. Dalam masalah keyakinan ini kita dibolehkan memilih pendapat yang sesuai dengan keyakinan hati.

\section{KESIMPULAN}

Dalam praktik tabungan PKK yang terdapat di Kampung Wiantre Distrik Skanto Kabupaten Keerom dengan ketentuan praktik yang dijalankan setiap nasabah tidak bisa di ambil sewaktu-waktu dan peminjam akan dikenakan bunga sebesar 2,5 persen. Dimana bunga 2,5 persen tersebut di bagi dua untuk nasabah 


\section{El Mudhorib: Jurnal Kajian Ekonomi dan Perbankan Syariah \\ Vol. 2 No. 1 Desember 2020 \\ E-ISSN: 2722-5615}

dan organisasi kemasyarakatan yaitu PKK di Kampung Wiantre Distrik Skanto Kabupaten Keerom untuk dana sosial. Dengan ketentuan tersebut maka praktik tersebut tidak masalah di pergunakan karena untuk kemaslahatan.

Dalam hukum islam kegiatan tabungan tabungan yang terdapat bunga ada beberapa ulama yang mengatakan bunga itu sama dengan riba jadi hukumnya haram sedang ulama lainnya mengatakan bahwa bunga itu berbeda dengan riba jadi diperbolehkan. Praktik tabungan Pemberdayaan kesejahteraan keluarga (PKK) diperbolehkan hal ini dilandasi oleh Al-Quran surat Al-Maidah : 2, bahwa dalam kegiatan menabung terdapat kegiatan saling tolong menolong sehingga membantu dalam kemaslahatan bersama.

\section{SARAN}

Untuk Masyarakat Hendaknya bersikap peduli terhadap keberadaan tabungan yang berbasis bagi hasil yang tidak menggunakan sistem bunga. Untuk Pemerintah hendaknya mendukung pihak-pihak yang ingin mengembangkan unitunit syariah yang dapat membantu meringankan perekonomian masyarakat sekitar. Untuk akademisi sebagai referensi di dunia akademik untuk penelitian selanjutnya terutama berkaitan dengan topik fikih muamalah.

\section{DAFTAR REFERENSI}

Nawawi, Hadari. (1991) Metode Penelitian Bidang Sosial. Yogyakarta : Gajah Mada University Press.

Soemitra Andri. (2009) Bank dan Lembaga Keuangan Syariah.Jakarta:Kencana.

Sjahdeini, Sutan Remy. (2007) Perbankan Islam dan Kedudukannya dalam Tata Hukum Perbankan Indonesia. Jakarta: Utama Grafiti.

Rozalinda, (2016) Fikih Ekonomi Syariah: Prinsip dan Implementasinya pada Sektor Keuangan Syariah, Jakarta: Rajawali Press.

Sugiono, (2013) Memahami Penelitian Kualitatif . Alfabeta:Bandung.

Yusuf, Muru. (2014) Metode Penelitian Kuantitatif, Kualitatif Dan Penelitian Gabungan Jakarta:Kencana.

Rachmadi, Usman, S.H., M.H.. Produk dan Akad Perbankan Syariah di Indonesia. Citra Aditya Bakti: Bandung, 2001Rachmadi. (2001). Produk dan Akad Perbankan Syariah di Indonesia. Citra Aditya Bakti: Bandung.

Zamzam dan Firdaus. (2018) Aplikasi Metodologi Penelitian. Yogyakarta: Deepublish.

Lerviana S. (2020, Maret 26). Wawancara Pribadi.

Nursiti. (2020, Maret 26). Wawancara Pribadi. 
El Mudhorib: Jurnal Kajian Ekonomi dan Perbankan Syariah

Vol. 2 No. 1 Desember 2020

E-ISSN: 2722-5615

Karsi. (2020, Maret 26). Wawancara Pribadi.

Subur. (2020, Maret 26). Wawancara Pribadi.

Marsiah. (2020, Maret 26). Wawancara Pribadi.

Endang Puwanti, (2020, Maret 26). Wawancara Pribadi.

Suwarni, (2020, Maret 26). Wawancara Pribadi.

Sulastri, (2020, Maret 26). Wawancara Pribadi.

Mahfudz Mudhor, (2020, Maret 29). Wawancara Pribadi. 